\title{
Sera from Patients with the Acquired Immunodeficiency Syndrome Inhibit Production of Interleukin-2 by Normal Lymphocytes
}

Jay P. Siegel, Julie Y. Djeu, Naomi I. Stocks, Henry Masur, Edward P. Gelmann, and Gerald V. Quinnan, Jr. Division of Virology, Office of Biologics Research and Review, Center for Drugs and Biologics, Food and Drug Administration; Critical Care Medicine Department, Clinical Center, and Medicine Branch, Division of Cancer Treatment, National Cancer Institute, National Institutes of Health, Bethesda, Maryland 20205

\begin{abstract}
We studied the effects of sera from patients with the acquired immunodeficiency syndrome (AIDS) on interleukin-2 (IL-2) production to help elucidate the mechanism of immunodeficiency. Compared with sera from healthy controls, sera from AIDS patients suppressed phytohemagglutinin (PHA)-induced IL-2 production by normal blood mononuclear cells. Sera from homosexual contacts of AIDS patients and from adults with acute cytomegalovirus infection generally lacked this suppressive activity. The effect of the AIDS sera could not be attributed to absence of a stimulatory or nutritive factor, to inactivation of IL-2, to inhibition of the $I L-2$ assay, nor to increased turnover of IL-2. The suppressive effect of the sera was not mediated by radiosensitive or $\mathbf{T} 8$ antigen-bearing suppressor cells or by increased prostaglandin production or decreased interleukin-1 production. The sera acted directly on the groups of cells that produce IL-2, T cells and large granular lymphocytes; suppression occurred at an early, probably pretranslational, stage. When cells were incubated with AIDS sera and then washed, the suppressive effect persisted. The sera did not cause direct or complement-mediated cytotoxic effects on normal mononuclear cells nor did they suppress PHA-induced interferon production, nor proliferation of $T$ lymphoblasts or lymphocyte lines. The suppressive effect was not mediated by interferon, cortisol, immunoglobulin $\mathbf{G}$ or $\mathbf{M}$, or immune complexes. The activity was stable at $\mathrm{pH} 3, \mathrm{pH} 10$, and $60^{\circ} \mathrm{C}$; inactivated at $100^{\circ} \mathrm{C}$; and not ether extractable. Because IL-2 plays a central role in the development of many immune responses, the serum factor(s) that inhibits IL-2 production could contribute significantly to the immunodeficiency of AIDS.
\end{abstract}

\section{Introduction}

The acquired immunodeficiency syndrome (AIDS) ${ }^{1}$ is frequently manifested by opportunistic infections resulting from a deficiency in cellular immunity (1-8). Although life-threatening infections with cytomegalovirus (CMV) are common (9, 10), patients with AIDS rarely develop cytotoxic $T$ cell responses to $\mathrm{CMV}$-infected cells, and they often have deficient natural

Received for publication 18 September 1984 and in revised form 12 February 1985.

1. Abbreviations used in this paper: AIDS, acquired immunodeficiency syndrome; anti-Tac, murine monoclonal antibody to human lymphocyte interleukin-2 receptors; CMV, cytomegalovirus; CTLL-2, cytotoxic T lymphocyte line 2; IFN, interferon; IL-2, interleukin-2; NK, natural killer, PBMC, peripheral blood mononuclear cell; PHA, phytohemagglutinin.

The Journal of Clinical Investigation, Inc.

Volume 75, June 1985, 1957-1964 killer (NK) cell activity $(11,12)$. Inasmuch as these two immunologic functions correlate with favorable outcome of CMV infection in allograft recipients $(13,14)$, they may well be important in the defense against CMV infection.

The lymphokine, interleukin-2 (IL-2), plays a role in the development of many aspects of cellular immunity including NK cell activity (15) and cytotoxic T lymphocyte activity (16, 17). When the peripheral blood mononuclear cells (PBMCs) of patients with AIDS are exposed in vitro to IL-2, often NK cell activity increases to normal levels and cytotoxic activity against CMV-infected cells develops (11). In that lymphocytes from patients with AIDS are deficient in NK cell and cytotoxic $\mathrm{T}$ cell activity and these deficiencies can often be corrected by exposure to IL-2 in vitro, it appears that there is a defect in AIDS at the level of stimulation of cytotoxic lymphocyte precursors by IL-2 in vivo. To assess the adequacy of the in vivo exposure of lymphocytes to IL-2 directly is difficult because there is no detectable IL-2 in sera from normal volunteers or patients with AIDS (unpublished observations). Because a serum factor in AIDS that suppresses IL-2 production could account for the abnormalities in cytotoxic activity described above, we tested sera from patients with AIDS for effects on the production of IL-2. We report here the existence of and information regarding a factor(s) in sera from AIDS patients that suppresses production of IL-2 by normal lymphocytes.

\section{Methods}

Subjects. All subjects with AIDS and their contacts were being followed at the Clinical Center, National Institutes of Health, Bethesda, MD. Approval for this study was obtained from the appropriate human subjects review committees and informed consent was obtained from all subjects in accordance with regulations for the protection of human subjects. The diagnosis of AIDS was made by the criteria established by the Centers for Disease Control (2). None of the subjects had received interferon (IFN) or other immunomodulating therapy before the time when serum was obtained. AIDS sera were obtained from AIDS patients, of whom all had opportunistic infections. Control sera were obtained from healthy adult laboratory workers. Other sera were obtained from healthy homosexual male volunteers who had been intimate contacts of men with AIDS. Sera from all these subjects were distributed in aliquots, stored at $-70^{\circ} \mathrm{C}$, and thawed immediately before use. Pooled normal human serum was prepared from sera from four or more healthy adult donors.

Five healthy adult males, seropositive for CMV, had been inoculated subcutaneously with live, nonattenuated Toledo 1 strain of CMV in a recently reported study (18). All developed clinical manifestations of CMV infection. Sera obtained immediately before inoculation and approximately $6 \mathrm{wk}$ after inoculation were stored at $-20^{\circ} \mathrm{C}$ and used in this study.

Preparation and treatment of PBMCs. Mononuclear cells were isolated from healthy donor blood or from buffy coat specimens provided by the Clinical Center Blood Bank, National Institutes of 
Health, Bethesda, MD, by use of Ficoll-Hypaque gradient centrifugation. The cells were washed twice and suspended in RPMI 1640 that contained $4 \mathrm{mM}$ glutamine, $5 \mathrm{mM}$ Hepes buffer, $50 \mathrm{U} / \mathrm{ml}$ penicillin, and $50 \mu \mathrm{g} / \mathrm{ml}$ gentamicin (medium). Adherent cells, large granular lymphocytes, and small $\mathrm{T}$ cells were isolated from PBMCs by using a modification of procedures described by others (19). Briefly, cells were incubated in plastic flasks for $2 \mathrm{~h}$ to separate adherent cells. The nonadherent cells were passed over a nylon wool column. The nonadsorbed cells (non-B lymphocytes) were centrifuged in a discontinuous Percoll (Pharmacia Fine Chemicals, Uppsala, Sweden) gradient. Fractions enriched in large granular lymphocytes and in small $\mathrm{T}$ lymphocytes were isolated and washed twice in medium.

In one experiment, $2.5 \times 10^{7}$ PBMCs in $100 \mu 1$ of medium were mixed with $25 \mu \mathrm{l}$ of OKT8 monoclonal antibody (Ortho Diagnostic Systems, Inc., Raritan, NJ). They were then incubated at room temperature with constant shaking for $30 \mathrm{~min}$. $25 \mu \mathrm{l}$ of rabbit complement (Gibco Laboratories, Grand Island, NY) were added, and the cells were incubated in a shaking water bath at $37^{\circ} \mathrm{C}$ for $45 \mathrm{~min}$. This concentration of complement, a 1:6 dilution, previously had been found to mediate antibody-dependent cytolysis while causing no nonspecific lysis of lymphocytes. An aliquot of cells was then counted in trypan blue and the cells were washed three times in medium.

Stimulation of PBMCs. Production of IL-2 was induced by culturing mononuclear cells in the presence of purified phytohemagglutinin (PHA; Burroughs-Wellcome, Research Triangle Park, NC). Normal donor mononuclear cells were suspended in medium and dispensed in $0.1-\mathrm{ml}$ aliquots containing $2.0 \times 10^{5}$ to $7.5 \times 10^{5}$ cells into 96 -well flat-bottomed microtiter plates (Becton, Dickinson \& Co., Oxnard, CA). Each well was supplemented with $25 \mu \mathrm{l}$ of the serum being tested ( $10 \%$ concentration). In some experiments, $25 \mu \mathrm{l}$ of pooled normal human serum was also added. PHA was added to a final concentration of either 2.5 or $10 \mu \mathrm{g} / \mathrm{ml}$. The final volume per well was brought to $250 \mu$ l with medium.

After incubation in a humidified atmosphere of $5 \% \mathrm{CO}_{2}$ in air at $37^{\circ} \mathrm{C}$ for $44 \mathrm{~h}, 150 \mu \mathrm{l}$ of supernatant was removed by pipette from each well for assay. In some experiments, the cells were then stained with $0.4 \%$ trypan blue and 200 cells per well were counted in a hemocytometer to assess cell viability.

In one experiment, cultures were supplemented with a murine monoclonal antibody to human lymphocyte IL-2 receptors, anti-Tac (20) (kindly provided by Drs. Warren Leonard and Warner Greene). Anti-Tac ascites was added at the initiation of PHA-stimulation at a final dilution of 1:1,000 which was found in preliminary experiments to maximize IL-2 yield. In other experiments, cultures were supplemented with indomethacin (Sigma Chemical Co., St. Louis, MO) which had been dissolved in ethanol at $2 \mathrm{mg} / \mathrm{ml}$ and stored at $-70^{\circ} \mathrm{C}$ and/or with interleukin-1 (Genzyme Corp., Boston, MA).

$I L-2$ assay. The measurement of IL-2 was based on its ability to support the proliferation of the IL-2-dependent murine lymphocyte line, CTLL-2 (21). Tests were performed in 96-well flat-bottomed microtiter plates. Samples to be tested for IL-2 activity were diluted in wells containing $50 \mu \mathrm{l}$ of medium supplemented with $5 \%$ pooled normal human serum. 4,000 CTLL-2 cells in $50 \mu 1$ of medium supplemented with $10 \%$ fetal calf serum (Gibco Laboratories) were then added to each well. This combination of sera was found to maximize sensitivity and minimize background activity in our assay system. After $16 \mathrm{~h}, 0.5 \mu \mathrm{Ci}$ of [methyl- ${ }^{3} \mathrm{H}$ ] thymidine was added to each well. At $20 \mathrm{~h}$ cells were harvested onto scintered glass filters with a MASH II harvester (M. A. Bioproducts, Walkersville, MD), and thymidine uptake was determined in a scintillation counter.

The potency of our laboratory reference standard for IL-2 (Associated Biomedic Systems, Inc., Buffalo, NY) was established by repeated pretesting in triplicate serial twofold dilutions. One unit of IL-2 was defined as the amount of IL- 2 present in $1 \mathrm{ml}$ of that mean dilution of the standard that induced $50 \%$ of maximal thymidine uptake by the CTLL-2 cells.

Samples to be tested for IL-2 activity were heated to $56^{\circ} \mathrm{C}$ for 10 min before testing to eliminate the inhibitory effect that some normal sera have in the IL-2 assay (22). Each sample was initially tested in serial dilutions in parallel with the standard. The graphs of the logarithm of counts per minute vs. the logarithm of the dilution for each sample and for the standard formed smooth curves which were nearly linear and parallel in the range of 5-75\% of maximal thymidine uptake. Each sample was retested in triplicate wells at a dilution selected to induce approximately $50 \%$ maximal thymidine uptake but not less than a 1:4 dilution. The amount of IL-2 in each sample was determined by comparing the median log counts per minute for the sample replicates to the standard curve to determine the IL-2 content of the wells and multiplying this value by the dilution factor. The IL2 levels thus determined were generally within $10 \%$ of levels determined by probit analysis (21), and were more reproducible.

Proliferation assays. Molt-3 and Raji cells were obtained from the Cell Biology Laboratory, Division of Virology, Food and Drug Administration. T lymphoblasts were prepared by culturing PBMCs at 5 $\times 10^{5} / \mathrm{ml}$ in medium supplemented with serum and PHA at $5 \mu \mathrm{g} / \mathrm{ml}$ for $2 \mathrm{~d}$ and then washing them and growing them in medium supplemented with serum and IL-2 at $20 \mathrm{U} / \mathrm{ml}$ for $5 \mathrm{~d}$. To assess serum effects on proliferation, Molt-3 and Raji cells were cultured in 96-well plates at $2 \times 10^{4}$ cells/well in $150 \mu$ l of medium supplemented to $10 \%$ with a test serum. T lymphoblasts were cultured in the same manner except they were additionally supplemented with IL-2 at 20 $\mathrm{U} / \mathrm{ml}$. For all these cell types and for PBMCs, $0.5 \mu \mathrm{Ci}$ of [methyl${ }^{3} \mathrm{H}$ ]thymidine was added at $40 \mathrm{~h}$ of culture; cells were harvested onto scintered glass filters with a MASH II harvester at $44 \mathrm{~h}$; and thymidine uptake was determined in a scintillation counter.

IFN assay. IFN in culture supernatants and sera was assayed by the inhibition of cytopathic effect of vesicular stomatitis virus as previously described (23), modified by the use of WISH human amnion cells rather than human foreskin fibroblasts. The titers are expressed in international units standardized with reference human leukocyte IFN (G-023-901-52).

Serum lymphocytotoxic activity. Sera were tested for direct lymphocytotoxicity and for complement-mediated lymphocytotoxicity as follows. Mononuclear cells from each of three normal donors were suspended at $1 \times 10^{6}$ cells $/ \mathrm{ml}$ and incubated at $37^{\circ} \mathrm{C}$ for $1 \mathrm{~h}$ in $50 \%$ serum and 50\% medium. After this, rabbit complement (Gibco Laboratories) was added at a $1: 6$ dilution. After an additional $1 \mathrm{~h}$ at $37^{\circ} \mathrm{C}$, cells were stained with trypan blue and 200 cells from each well were counted in a hemocytometer to determine viability.

Adsorption and assay of immunoglobulins. Staphylococcal protein A-CL-Sepharose 4B powder (Pharmacia Fine Chemicals) was placed in medium overnight to allow swelling to a gel. To 1 vol of each test serum was added 2.8 vol of slurry containing $50 \%$ protein A-Sepharose gel by volume. This mixture was incubated for $1 \mathrm{~h}$ at room temperature with frequent agitation and then centrifuged at $400 \mathrm{~g}$ for $10 \mathrm{~min}$. Each supernatant fluid was collected and added to the IL-2 production assay so that $10 \%$ of final volume was adsorbed serum.

IgG fraction rabbit anti-human IgM (Cappel Laboratories, Cochranville, PA) was covalently linked to cyanogen bromide-activated Sepharose 4B (Pharmacia Fine Chemicals) after the manufacturer's recommended protocol. These beads were used to adsorb IgM from test sera after the protocol described immediately above for the adsorption of IgG. All IgG and IgM levels, before and after adsorption, were measured by single radial immunodiffusion assay (24).

Cortisol levels. Serum cortisol levels were measured by radioimmunoassay by Bio-Science Laboratories, Columbia, MD.

\section{Results}

Effects of sera on IL-2 production. Sera from AIDS patients and normal controls were tested at a concentration of $10 \%$ for their effects on IL-2 production in five experiments that used different mononuclear cell donors for each experiment. The means of the five results for each serum are shown in Fig. 1. As can be seen, IL-2 production in the presence of individual 


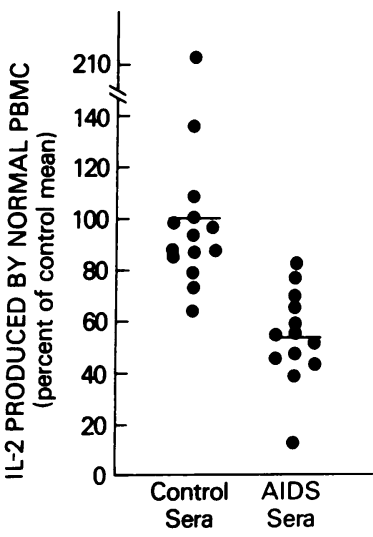

Figure 1. The effect of sera from patients with AIDS on IL-2 production by normal PBMCs stimulated with PHA at $10 \mu \mathrm{g} / \mathrm{ml}$. Each culture was supplemented to $10 \%$ with serum from an AIDS patient $(n=13)$ or a healthy control $(n$ = 14). At $40 \mathrm{~h}$, supernatants were harvested and IL-2 was measured using a CTLL-2 proliferation assay. Each point represents the mean of results of five experiments on different PBMC with one serum.

sera from patients with AIDS was generally lower than that in the presence of normal control sera $(P<0.01)$.

Four additional AIDS sera (not included among the 13 sera whose test results are depicted in Fig. 1) and four control sera were tested for their effects on IL-2 production by mononuclear cells stimulated by PHA at two concentrations, 10 and $2.5 \mu \mathrm{g} / \mathrm{ml}$. All cultures in this experiment contained pooled normal human serum at $10 \%$. Results are shown in Fig. 2. At a PHA concentration of $10 \mu \mathrm{g} / \mathrm{ml}$, mean IL-2 production in the presence of AIDS sera was $59 \%$ of control (30 vs. $51 \mathrm{U} / \mathrm{ml}$ ); at $2.5 \mu \mathrm{g} / \mathrm{ml}$, it was only $24 \%$ of control $(1.3$ vs. $5.5 \mathrm{U} / \mathrm{ml}$ ).

To acquire information regarding the specificity for AIDS of the finding of serum suppression of IL-2 production, we tested in parallel sera from six adult controls, eight patients with AIDS, seven healthy homosexual contacts of AIDS patients, and sera obtained from five adult males before and during experimental, symptomatic, secondary CMV infections. All cultures in this experiment also contained pooled normal human serum at $10 \%$. The results of this experiment are indicated in Fig. 3. Of interest is that the one homosexual control whose serum appeared to suppress IL-2 production subsequently developed signs and symptoms of hepatitis. The serum we tested was subsequently determined to be positive for hepatitis B surface antigen. At 1 yr of follow-up he remains

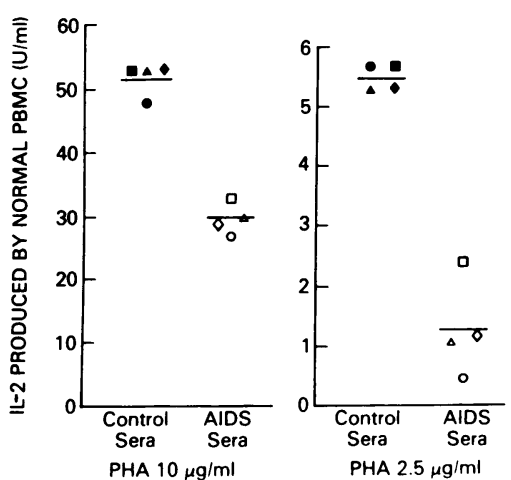

Figure 2. The effect of sera from patients with AIDS on IL-2 production by normal PBMCs stimulated with different concentrations of PHA. The four solid symbols indicate results obtained in cultures supplemented with $10 \%$ serum from each of four healthy controls; the open symbols represent four patients with AIDS. The bars represent the mean for each group.

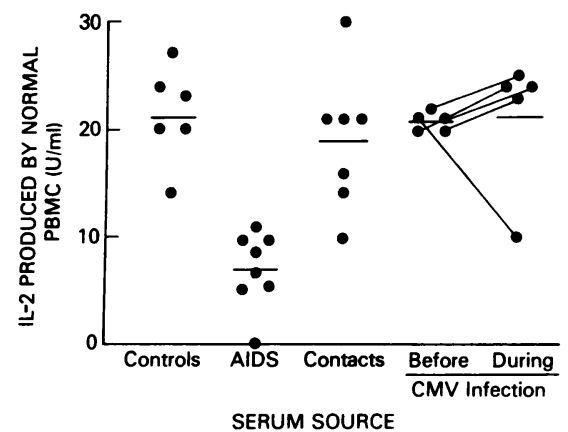

Figure 3. The effects of sera from a variety of sources on IL-2 production by normal PBMCs stimulated with PHA. The contacts did not have AIDS but had had recurrent intimate contact with individuals who had AIDS or who later developed AIDS. The five individuals with CMV infection were seropositive individuals who were inoculated subcutaneously with low passage CMV (18). The bars represent the mean for each group.

positive for hepatitis B surface antigen. None of the seven contacts has developed signs of AIDS or lymphadenopathy. The subject with CMV infection whose serum caused suppression of IL-2 production had fever, splenomegaly, and atypical lymphocytosis but lacked detectable viruria or viremia at the time the serum was drawn. Only one other of these five subjects developed fever and splenomegaly but all developed signs and/or symptoms of CMV infection (18).

Nature of the serum effect. We next performed experiments to determine whether the lower IL-2 levels found in the presence of AIDS sera resulted from a suppressive effect or from the absence of a stimulatory or nutritive effect. Preliminary experiments had indicated little or no differences in IL-2 production in concentrations of normal serum ranging from 5 to $20 \%$. As can be seen in Fig. 4, when pooled normal human serum was added to all cultures at a concentration of $10 \%$, IL-2 production was still suppressed by the AIDS sera $(P$ $<0.01)$ to a degree comparable to the suppression observed in the absence of pooled normal human serum. In subsequent IL-2 production experiments, medium was supplemented with 5 or $10 \%$ pooled normal human serum in addition to test sera.

Experiments were performed to determine whether the AIDS sera exerted their effects through inactivation of IL-2 or through inhibition of proliferation of the cells used to assay for IL-2 rather than through suppression of IL-2 production. To each of 24 aliquots of medium we added a test serum (11 control and 13 AIDS) to achieve a final concentration of $10 \%$, and our laboratory standard IL-2 to achieve a final concentra-

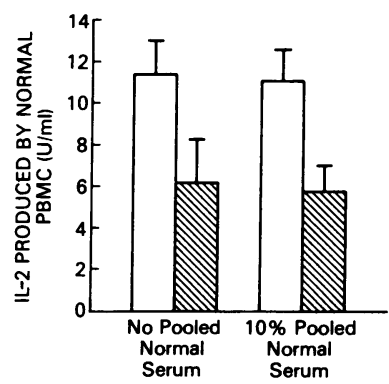

Figure 4. The effect of supplementation with pooled normal human serum on IL-2 production by PHA-stimulated cultures on PBMCs supplemented with $10 \%$ AIDS serum ( $₫ ; n=13)$ or $10 \%$ control serum $(\square ; n=12)$. The mean and SE are shown for each group. 
tion of $20 \mathrm{U} / \mathrm{ml}$. We then assayed the IL-2 in the serum-IL-2 mixtures both immediately upon mixing and after $44 \mathrm{~h}$ of incubation at $37^{\circ} \mathrm{C}$. At time 0 the results of the IL-2 assay were $20.8 \pm 1.8 \mathrm{U} / \mathrm{ml}($ mean $\pm \mathrm{SD}$ ) for the control sera and $20.3 \pm 1.7 \mathrm{U} / \mathrm{ml}$ for the AIDS sera $(P>0.1)$. At $44 \mathrm{~h}$ the results were $17.9 \pm 3.9$ and $19.9 \pm 2.2 \mathrm{U} / \mathrm{ml}$, respectively $(P>0.1)$.

Experiments were then performed to determine whether the reduced levels of IL-2 in the PHA-stimulated cultures containing AIDS sera resulted from increased uptake of IL-2 by the mononuclear cells rather than from decreased production of IL-2. The results are shown in Table I. Lymphocyte proliferation was measured during PHA stimulation because increased IL-2 uptake might be reflected by increased proliferation. In the presence of AIDS sera proliferation was depressed.

Additionally, anti-Tac monoclonal antibody, which specifically binds the lymphocyte IL-2 receptor (20), was added to PHA-stimulated IL-2 production cultures to block IL-2 uptake. As expected, the addition of anti-TAC increased the levels of IL-2 present in cultures containing either AIDS or normal sera. Nevertheless, the levels of IL-2 found in the cultures with AIDS sera, in comparison with those in the cultures with control sera, remained depressed to the same relative extent as in the absence of anti-Tac antibody.

Timing and target of the suppressive effect. To further elucidate the nature of the effect of AIDS sera on IL-2 production, individual aliquots of normal mononuclear cells were incubated at $37^{\circ} \mathrm{C}$ for $24 \mathrm{~h}$ at $10^{7} \mathrm{cells} / \mathrm{ml}$ in medium supplemented with $20 \%$ serum from one of five healthy controls or one of 10 AIDS patients. Cells were then washed twice and stimulated with PHA in medium supplemented with $10 \%$ pooled normal serum plus either an additional $10 \%$ pooled normal serum or $10 \%$ of the test serum used in the incubation. As shown in Fig. 5, IL-2 production by cells that had been preincubated in AIDS sera was reduced regardless of whether the AIDS sera were present during stimulation with PHA.

In another experiment, PBMCs were stimulated with PHA in the presence of pooled normal human serum. At various intervals thereafter, either an AIDS serum or additional pooled normal human serum was added. The AIDS serum caused the greatest suppression of IL-2 production when added within 1 $\mathrm{h}$ of PHA stimulation. When the serum was added 2 or $4 \mathrm{~h}$

Table I. Effects of Sera on Thymidine Uptake by and IL-2 Yield of PHA-stimulated Mononuclear Cells in the Presence or Absence of Antibody to the IL-2 Receptor

\begin{tabular}{lllll}
\hline & \multicolumn{3}{l}{ Without anti-Tac } & \\
\cline { 3 - 4 } $\begin{array}{l}\text { Source } \\
\text { of sera }\end{array}$ & $n$ & $\begin{array}{l}\text { Thymidine } \\
\text { uptake }\end{array}$ & IL-2 yield & $\begin{array}{l}\text { With anti-Tac* } \\
\text { IL-2 yield }\end{array}$ \\
\hline & & $c p m \times 10^{-3}$ & $U / m l$ & $U / m l$ \\
Controls & 5 & $65 \pm 12 \ddagger$ & $45 \pm 3$ & $66 \pm 4$ \\
AIDS & 7 & $26 \pm 12$ & $21 \pm 6$ & $31 \pm 8$ \\
& & & $(47 \%$ of control) & $(47 \%$ of control)
\end{tabular}

* Cultures were supplemented with a 1:1,000 dilution of murine ascites containing anti-Tac, a monoclonal antibody to the human lymphocyte IL-2 receptor.

$\ddagger$ Results expressed as mean \pm SE.

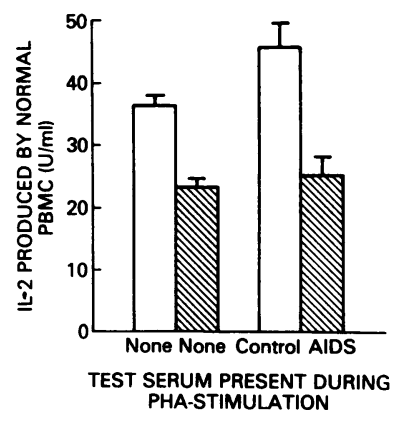

Figure 5. The effect of preincubation in AIDS serum on IL-2 production by normal PBMCs stimulated with PHA. PBMCs were incubated for $24 \mathrm{~h}$ at $37^{\circ} \mathrm{C}$ in medium supplemented to $20 \%$ with serum from one of five controls (), or from one of 10 AIDS patients ( $\square)$. Cells were then washed twice and stimulated with PHA in medium supplemented to $20 \%$ with pooled normal human

serum(two bars on left) or to $10 \%$ with pooled normal human serum and to an additional $10 \%$ with the same serum used during preincubation (two bars on right). The mean and SE are shown for each group.

after stimulation, suppression was less pronounced; at $8 \mathrm{~h}$, no suppression was observed (Fig. 6).

To determine whether the sera act by suppressing IL-2 production directly or by augmenting activity of cells that suppress IL-2 production, sera were tested for their effect on IL-2 production by PBMCs that had been treated to abrogate normal suppressor mechanisms. Indomethacin was used to block prostaglandin production by monocytes; the monoclonal antibody, OKT8, and complement were used to lyse suppressor and cytotoxic T cells; and gamma irradiation was used to inactivate radiosensitive suppressor cells. The data summarized in Table II indicate that each of the treatments employed to block suppressors of IL-2 production resulted in increased IL2 production in the presence of both normal and AIDS sera. Nevertheless, the degree of suppression of IL-2 production by AIDS sera remained fairly constant despite these treatments of PBMCs.

Various subpopulations of PBMCs were exposed to an AIDS serum to determine which cells were affected directly by the serum. Compared with IL-2 production by cells not exposed to AIDS serum, IL-2 production by small $\mathrm{T}$ cells preincubated in AIDS serum and then mixed with plastic adherent cells was depressed whereas IL-2 production by small $T$ cells not exposed to AIDS serum mixed with plastic adherent cells that had been preincubated in AIDS serum was not depressed (Fig. 7). Additionally, IL-2 production by purified large granular lymphocytes was suppressed when AIDS serum was present during PHA stimulation.

Exogenous interleukin-1 was added to cultures of PBMCs at the time of PHA stimulation to determine whether this might overcome the suppressive effect of the AIDS sera. The

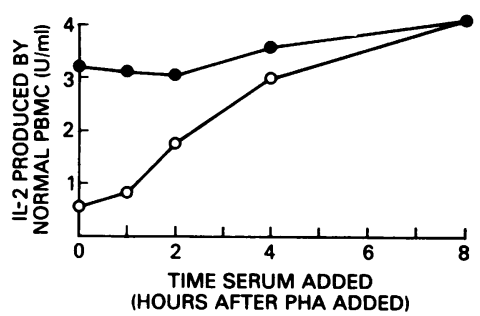

Figure 6. The effects of an AIDS serum and pooled normal serum on PHAstimulated IL-2 production by normal PBMCs as a function of the time at which the serum was added to the culture. Multiple cultures of PBMCs in medium supplemented to $5 \%$ with pooled normal human serum were stimulated with PHA at $2.5 \mu \mathrm{g} / \mathrm{ml}$. At various intervals thereafter, cultures were supplemented with either additional $10 \%$ pooled normal serum (๑) or with $10 \%$ serum from an AIDS patient (O). Supernatant fluids were collected at $\mathbf{4 0}$ hours. 
Table II. Effect of AIDS Sera on IL-2

Production by PHA-stimulated Mononuclear Cells

Treated to Block Cellular Suppression

\begin{tabular}{|c|c|c|c|c|c|}
\hline \multirow[b]{2}{*}{ Expt. } & \multirow[b]{2}{*}{ Treatment of PBMCs } & \multicolumn{4}{|c|}{$\begin{array}{l}\text { IL-2 production (\% of mean of two controls) } \\
\text { Serum added during PHA stimulation }\end{array}$} \\
\hline & & $\begin{array}{l}\text { Normal } \\
\text { pool }\end{array}$ & Control & AIDS-1 & AIDS-2 \\
\hline & & $U / m l$ & $U / m l$ & $\begin{array}{l}U / m l \\
(\%)\end{array}$ & $\begin{array}{l}U / m l \\
\text { (\%) }\end{array}$ \\
\hline \multirow[t]{2}{*}{1} & - & 55 & & $20(35)$ & \\
\hline & Indomethacin $1 \mu \mathrm{g} / \mathrm{ml}$ & 74 & & $22(30)$ & \\
\hline \multirow[t]{5}{*}{2} & - & 15 & 18 & $9(53)$ & $4(22)$ \\
\hline & 1,200 rads & 28 & 24 & $12(46)$ & $8(30)$ \\
\hline & OKT8 + $\mathrm{C}^{\prime}$ & 22 & 25 & $14(60)$ & $3(14)$ \\
\hline & 1,200 rads & & & & \\
\hline & + indomethacin & 48 & 54 & $30(59)$ & $14(27)$ \\
\hline
\end{tabular}

PBMCs were treated with gamma irradiation or with monoclonal antibody and complement immediately before PHA stimulation; indomethacin was added to PBMCs at the same time as PHA. PHA stimulation occurred in medium supplemented to $10 \%$ with pooled normal human serum and to an additional $10 \%$ with either pooled normal human serum, an individual normal control serum, or serum from one of two patients with AIDS. At $40 \mathrm{~h}$, supernatants were tested for IL-2 level in a CTLL-2 proliferation assay. Results for the two AIDS sera are alternatively expressed (in parentheses) as percent of the mean result for the two controls.

data shown in Table III indicate that the addition of excess exogenous interleukin-1 had no significant effect on the suppression of IL-2 production by AIDS sera. Potency of this interleukin-1 was confirmed in a mouse thymocyte assay kindly performed by Dr. Theresa Gerrard.

Selectivity of the suppressive effect. In three of the IL-2 production experiments we stained the mononuclear cells with trypan blue to assess viability after harvesting the supernatants for IL-2 assays. In all cases, including the experiment in which

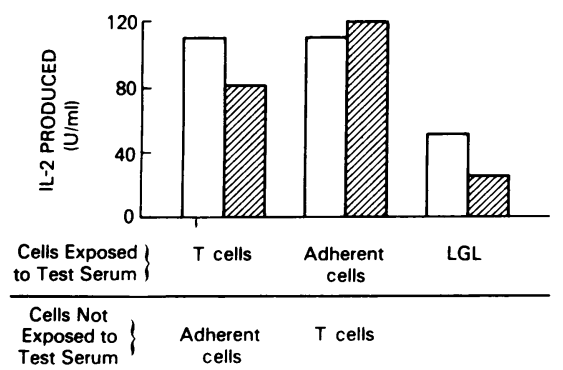

Figure 7. The effect of serum from a patient with AIDS on various cell populations involved in IL-2 production. Cell populations were isolated from PBMCs by plastic adherence, passage over a nylon wool column, and Percoll gradient centrifugation. Small $\mathrm{T}$ cells and plastic adherent cells were preincubated for $24 \mathrm{~h}$ in medium supplemented to $20 \%$ with AIDS serum ( $($ ) or pooled normal human serum ( $\square$ ) and were washed twice in medium. The preincubated $T$ cells were supplemented with autologous adherent cells and vice versa at a $T$ cell to adherent cell ratio of 9:1. These mixtures were then stimulated with PHA in medium supplemented to $10 \%$ with pooled normal human serum only. Large granular lymphocytes (LGL) were held for $24 \mathrm{~h}$ in medium supplemented to $20 \%$ with pooled normal human serum, washed, and then stimulated with PHA in medium supplemented to $10 \%$ with pooled normal serum and to an additional $10 \%$ with AIDS serum or pooled normal human serum.
Table III. Effect of Sera on IL-2 Production by PHA-stimulated Mononuclear Cells Supplemented with Interleukin-I

\begin{tabular}{llll}
\hline & & \multicolumn{2}{l}{ IL-2 production } \\
\cline { 3 - 4 } & & Control sera $(n=4)$ & AIDS sera $(n=3)$ \\
\hline & & $U / m l$ & $U / m l$ \\
Interleukin-1 & $0 \mathrm{U} / \mathrm{ml}$ & $146 \pm 15^{*}$ & $52 \pm 8$ \\
Interleukin-1 & $3 \mathrm{U} / \mathrm{ml}$ & $146 \pm 16$ & $45 \pm 3$ \\
Interleukin-1 & $10 \mathrm{U} / \mathrm{ml}$ & $133 \pm 15$ & $48 \pm 14$ \\
& & & \\
\hline
\end{tabular}

PBMCs in medium supplemented to $5 \%$ with pooled normal human serum and to an additional $10 \%$ with a control or AIDS sera were stimulated with PHA in the presence of indomethacin at $1 \mu \mathrm{g} / \mathrm{ml}$ and interleukin- 1 at 0,3 , or $10 \mathrm{U} / \mathrm{ml}$.

* Results expressed as mean $\pm \mathrm{SE}$

cells were preincubated in $20 \%$ test serum for $24 \mathrm{~h}$ prior to PHA stimulation, viability after stimulation was $\sim 90 \%$ or greater and mean viability of the cells exposed to control sera and those exposed to AIDS sera did not differ significantly.

Levels of IFN produced by normal mononuclear cells in response to PHA stimulation in the presence of sera from controls and patients with AIDS were measured in the IL-2 production experiments. Mean IFN production was 1,389 IU/ $\mathrm{ml}$ in the presence of 12 control sera and $1,402 \mathrm{IU} / \mathrm{ml}$ in the presence of 13 AIDS sera.

Eight AIDS sera that had consistently suppressed IL-2 production were tested for their effects on proliferation of IL-2-dependent T lymphoblasts, of Molt-3, an IL-2-independent $T$ cell line, and of Raji, a B cell line. As indicated in Table IV, no significant effect of the sera on the thymidine uptake of any of the cell types was observed.

Lack of relationship of serum IFN, cortisol, and immunoglobulin to suppression of $I L-2$ production. Experiments were performed to determine if the suppressive activity in sera from AIDS patients could be attributed to IFN, cortisol, immunoglobulin, or immune complexes. Of 12 AIDS sera tested for IFN, seven lacked IFN and five had measurable IFN, each at a level of $625 \mathrm{IU} / \mathrm{ml}$. In five experiments, mean IL-2 production was inhibited to $53 \pm 23 \%$ (mean \pm SD) of control in the presence of the seven AIDS sera lacking IFN and $51 \pm 11 \%$ of control in the presence of the five sera with IFN.

Six of our serum specimens from AIDS patients were tested for cortisol. Cortisol levels in five were within normal range (5-20 $\mu \mathrm{g} / 100 \mathrm{ml} ; 0.14-0.55 \mu \mathrm{mol} / \mathrm{liter})$ and in the other it was $43.2 \mu \mathrm{g} / 100 \mathrm{ml}(1.19 \mu \mathrm{mol} / \mathrm{liter})$. The serum with

Table IV. Effects of Sera on Thymidine

Uptake by Various Lymphoid Cells

\begin{tabular}{lllll}
\hline \multirow{5}{*}{$\begin{array}{l}\text { Serum } \\
\text { source }\end{array}$} & $n$ & \multicolumn{2}{l}{ Thymidine uptake } & \\
\cline { 3 - 5 } & $n$ & T lymphoblasts & Molt-3 & Raji \\
\hline & & $c p m$ & $c p m$ & $c p m$ \\
Controls & 5 & $18,670 \pm 1,368^{*}$ & $4,490 \pm 391$ & $79,283 \pm 3,899$ \\
AIDS & 8 & $16,025 \pm 1,023 \ddagger$ & $4,617 \pm 350 \ddagger$ & $73,088 \pm 2,736 \ddagger$
\end{tabular}

* Results expressed as mean $\pm \mathrm{SE}$.

$\ddagger P$ (vs. control) $>0.05$. 
elevated cortisol did not cause greater suppression of IL-2 production than the mean suppression caused by the other five sera. Furthermore, when an IL-2 production assay with $10 \%$ pooled normal serum was supplemented with exogenous hydrocortisone at a concentration of $0.1 \mu \mathrm{g} / \mathrm{ml}$ (equivalent to $100 \mu \mathrm{g} / 100 \mathrm{ml}$ or $2.75 \mu \mathrm{mol} /$ liter in the undiluted serum), IL2 production was reduced by only $5 \%$.

We also tested four control sera and four AIDS sera before and after adsorption of IgG by protein A-CL-Sepharose 4B. As shown in Table $\mathrm{V}$, suppressive activity in the AIDS sera was not significantly altered after removal of $\sim 90 \%$ of total IgG. In a separate experiment (results not shown) an AIDS serum with less IgG $(8.0 \mathrm{~g} / \mathrm{liter})$ was similarly adsorbed yielding a final IgG level of $0.29 \mathrm{~g} /$ liter ( $96 \%$ removal of $\mathrm{IgG}$ ) with no loss of inhibitory effects on IL-2 production.

Three sera, two from patients with AIDS and one pooled normal human serum, were adsorbed with anti-human IgMSepharose 4B. After adsorption, IgM was below the limits of detection $(0.032 \mathrm{~g} /$ liter $)$ in all three sera. PBMCs were stimulated with PHA in medium supplemented to $10 \%$ with pooled normal serum and to an additional $10 \%$ with one of these three sera either before or after adsorption. Before adsorption, the two AIDS sera suppressed IL-2 production to $9 \%$ of that in the culture with pooled normal serum; after adsorption, they suppressed production to $4 \%$ of control (data not shown).

To further assess the role of immunoglobulin, four AIDS sera were tested for lymphocytotoxicity against mononuclear cells from three normal donors. Compared with mononuclear cells incubated with normal sera, no significant decrease in viability was observed as a result of incubation with any of the AIDS sera, regardless of whether complement was added.

Preliminary characterization of the suppressive activity in AIDS sera. The suppressive activity was not lost after incubation at $\mathrm{pH} 3$ or 10 for $6 \mathrm{~h}$ followed by neutralization. The activity persisted through heating to $60^{\circ} \mathrm{C}$ for $6 \mathrm{~h}$ but $\sim 75 \%$ of activity was lost during heating to $100^{\circ} \mathrm{C}$ for $5 \mathrm{~min}$. Suppressive activity persisted after three cycles of freezing and thawing. The activity was not ether extractable.

\section{Discussion}

The results presented in this report indicate that sera from AIDS patients contain a factor or factors that suppress IL-2 production by PHA-stimulated mononuclear cells. This suppression could not have resulted from a deficiency of a stimulatory or nutritive factor because it was not overcome by addition of pooled normal human sera. The AIDS serum did not directly inactivate IL-2 nor interfere with the effects of IL-2 on the murine cell line used to assay for IL-2. Indeed,

Table V. Effects of Adsorption of Sera with Staphylococcal Protein A on IgG Levels and Suppression of IL-2 Production

\begin{tabular}{|c|c|c|c|c|c|}
\hline \multirow[b]{2}{*}{$\begin{array}{l}\text { Serum } \\
\text { source }\end{array}$} & \multirow[b]{2}{*}{$n$} & \multicolumn{2}{|c|}{ Mean serum IgG levels } & \multicolumn{2}{|c|}{ IL-2 produced } \\
\hline & & $\begin{array}{l}\text { Before } \\
\text { adsorption }\end{array}$ & $\begin{array}{l}\text { After } \\
\text { adsorption }\end{array}$ & $\begin{array}{l}\text { Unadsorbed } \\
\text { sera }\end{array}$ & $\begin{array}{l}\text { Adsorbed } \\
\text { sera }\end{array}$ \\
\hline & & $m g / m l$ & $m g / m l$ & $U / m l$ & $U / m l$ \\
\hline Controls & 4 & 15.1 & 0.8 & 33 & 32 \\
\hline AIDS & 4 & 21.1 & 2.2 & 14 & 14 \\
\hline
\end{tabular}

the sera must have exerted their suppressive effects directly on mononuclear cells rather than on medium, PHA, or IL-2 because suppressed IL-2 production was demonstrated by cells that were preincubated with sera from patients with AIDS and then washed. That the sera caused decreased production of IL-2 rather than increased consumption of IL-2 by proliferating lymphocytes is indicated by the findings that mononuclear cells stimulated in the presence of AIDS sera proliferated less than cells stimulated in control sera, and they yielded less IL2 even when stimulated in the presence of anti-Tac monoclonal antibody which blocks IL-2 uptake.

Several conclusions may be drawn from our data regarding the mechanism of serum suppression of IL-2 production in AIDS. Suppression was not mediated through stimulation of radiosensitive or T8 antigen-bearing suppressor cells inasmuch as suppression occurred even after PBMCs were irradiated with 1,200 rads or treated with OKT8 monoclonal antibody and complement. Nor did the suppression of IL-2 production result from suppression of monocyte interleukin-1 production because addition of excess exogenous interleukin- 1 did not overcome suppression of IL-2 production. Neither could serum suppression be attributed to augmentation of monocyte-mediated prostaglandin production, a proposed mechanism for normal regulatory inhibition of IL- 2 production $(25,26)$, in that suppression occurred in the presence of indomethacin, an agent which blocks prostaglandin synthetase activity. Furthermore, our studies on subpopulations of PBMCs indicate that AIDS sera exerted their effect not on monocytes but on the cell types that produce IL-2, T lymphocytes and large granular lymphocytes (27).

The findings that no suppression occurred when AIDS serum was added $8 \mathrm{~h}$ after PHA and submaximal suppression occurred when it was added at 2-4 h should be viewed in light of the fact that IL-2 does not appear in medium until 12-16 $\mathrm{h}$ after addition of PHA to PBMCs under the conditions that we employ (unpublished data). Thus, the suppression caused by AIDS sera probably does not occur at the level of translation or secretion but more likely occurs at a transcriptional or pretranscriptional level. The suppression was selective for IL2 production in that PHA-induced IFN production was not suppressed, viability was not diminished, and the sera did not suppress proliferation of $\mathrm{T}$ lymphoblasts, a $\mathrm{T}$ cell line, or a $\mathrm{B}$ cell line. Also of note regarding the mechanism of suppression is that lymphocytes incubated in AIDS serum for $24 \mathrm{~h}$ and then washed remained suppressed in their ability to produce IL-2. This may reflect either internalization of suppressor substance(s) in the lymphocytic cytoplasm or an effect of the suppressor substance(s) on lymphocytes which is not readily reversible.

Although our tests generally discriminated well between AIDS sera and control sera (particularly at the lower dose of PHA), there were two noteworthy examples of overlap. One of several healthy homosexual men had serum that suppressed IL-2 production into the range observed with the AIDS sera. This subject was a recurrent sexual contact of a patient with AIDS; however, he remains free of AIDS at 12 mo of followup. Also of note is that his serum was hepatitis B surface antigen positive, and he subsequently developed signs and symptoms of acute and chronic hepatitis. One of five healthy subjects given experimental secondary CMV infection also developed serum suppressive activity comparable to that observed in AIDS patients. These five subjects demonstrated 
immunologic abnormalities typical of systemic CMV infection (18). We have yet to determine whether the suppressive factor(s) in the subject with hepatitis and the subject with CMV infection is (are) identical to the factor(s) in patients with AIDS. Therefore the serum suppression observed in AIDS may be specific for AIDS or may represent a less specific response to viremia, immunosuppression, and/or other factors yet to be determined.

We performed tests to determine whether the factor(s) in sera from AIDS patients which suppressed IL-2 production was abnormal IFN, elevated cortisol, antibodies, or immune complexes. Acid-labile $\alpha$ IFN is often present in sera of patients with AIDS (28). We found no correlation between the presence of IFN in AIDS sera and the suppressive effects on IL-2 production. Cortisol can impair IL-2 production $(16,29)$ and may be elevated during illness, but the cortisol levels that we found in most AIDS sera were within normal limits, and none were high enough to account for the suppressive effect on IL2 production. Sera were treated with immunoadsorbents to remove $\mathrm{IgG}, \mathrm{IgM}$, and immune complexes. Removal of $90 \%$ of IgG from several sera did not diminish their suppressive activity; nor did removal of nearly all IgM from two sera. Additionally, we found no antibody and complement-mediated lymphocytotoxic activity in the four sera we tested.

The suppressive activity was stable at $\mathrm{pH} 3$ and 10 , stable at $60^{\circ} \mathrm{C}$, inactivated at $100^{\circ} \mathrm{C}$, and not extracted by ether. Since human $\mathrm{T}$ cell lymphotropic virus III is inactivated by treatment at $60^{\circ} \mathrm{C}$ for $6 \mathrm{~h}$ (unpublished data) and is also ether sensitive, these findings indicate that the suppressive activity does not require live human $T$ cell lymphotropic virus III in the sera. The lack of ether extractability suggests that the activity is not a lipid or other highly hydrophobic molecule.

The degree of suppression of IL-2 production that we observed may underestimate the actual degree of suppression attributable to the serum factor in vivo. When the concentration of PHA was lowered and less IL-2 was produced, the suppression was of a relatively greater degree. When we employ antigenic stimuli such as allogenic cells or influenza virusinfected lymphocytes instead of PHA, we typically find even lower levels of IL-2 produced (generally $<2 \mathrm{U} / \mathrm{ml}$; unpublished observations). The suppressive effect of the AIDS serum factor(s) might be more profound in vivo than in this study because of the weaker antigenic stimuli, the longer period of exposure of lymphocytes to serum, and because the factor(s) should be 10fold more concentrated in the patients' circulation than in culture media supplemented to $10 \%$ with serum.

The nature of the effect of the serum suppressive factor(s) suggests an important role in the pathophysiology of AIDS. As indicated in the introduction, many patients with AIDS and CMV infection lack cytotoxic lymphocytes directed against CMV-infected cells and are deficient in NK activity yet have IL-2-responsive precursor cells, $(11,12)$. This arrest in the development of mature cytotoxic effector cells could readily be explained by suppression of IL-2 production in vivo; in such a manner the serum factor that we describe could contribute significantly to the increased susceptibility to infection of patients with AIDS. Furthermore, due to the central role that IL-2 plays in the development of many immune responses, impaired IL-2 production could account for several of the previously described immunologic abnormalities in patients with AIDS such as low NK activity $(11,12)$ and impaired delayed-type hypersensitivity reaction to skin test antigens (3-8). Because the suppressive activity of AIDS sera persisted in normal lymphocytes after washing, it might also contribute to functional abnormalities observed in AIDS lymphocytes when stimulated in vitro such as the impaired proliferative response to mitogens (3-6). Additionally, suppression of IL-2 production could account for the suppression of mitogen-induced proliferation of normal lymphocytes attributed to sera from patients with AIDS (30). Indeed, because IL-2 supports the proliferation of helper and suppressor $\mathrm{T}$ lymphocytes, any immunologic function involving regulation by these cells could be altered by the factor suppressing IL-2 production.

The finding that important immunologic abnormalities in AIDS may be attributable to a serum factor(s) has significant implications regarding research into the immunopathology of AIDS and regarding the clinical management of AIDS. The serum factor may be produced either by an infectious agent of AIDS or by the patient in response to the agent. Evidence strongly suggests that a retrovirus is probably the causative agent of AIDS (31-33); it is of interest that inactivated feline leukemia retrovirus particles can suppress IL-2 production by lymphocytes (34). Additionally, soluble factors which suppress IL-2 production have been reported to be produced by spleen cells (35), melanoma cells (36), and monocytes $(25,26)$. Cultures of mononuclear cells from AIDS patients have been reported to produce an immunosuppressive factor, but this factor could not account for the serum suppressive effect that we observed in that it did not inhibit proliferation of PBMCs in response to PHA (37). We are currently conducting studies designed to determine the source of the serum factor, to understand better its actions, and to purify and characterize it. These studies should provide new insights into the immunopathology of AIDS and may lead to techniques for blocking the production of the factor, removing or inactivating it, or blocking, bypassing, or countering its effects and may thus contribute to the rational design of immunotherapy for AIDS.

\section{Acknowledgments}

We are indebted to Dr. H. Clifford Lane and Dr. Anthony S. Fauci for providing sera from and clinical data regarding many of the patients in this study and to Dr. Alain S. Rook for his invaluable assistance in acquiring specimens and in providing data regarding the subjects.

\section{References}

1. Jaffe, H. W., D. J. Bregman, and R. M. Selik. 1983. Acquired immune deficiency syndrome in the United States: the first 1,000 cases. J. Infect. Dis. 148:339-345.

2. Centers for Disease Control. 1984. Update: acquired immunodeficiency syndrome (AIDS)-United States. Morbidity and Mortality Weekly Report. 33:337-339.

3. Gottlieb, M. S., R. Schroff, H. M. Schanker, J. D. Weisman, P. T. Fan, R. A. Wolf, and A. Saxon. 1981. Pneumocystis carinii pneumonia and mucosal candidiasis in previously healthy homosexual men: evidence of a new acquired cellular immunodeficiency. $N$. Engl. J. Med. 305:1425-1430.

4. Masur, H., M. A. Michelis, J. B. Greene, I. Onorato, R. A. Vande Stouwe, R. S. Holzman, G. Wormser, L. Brettman, M. Lange, H. W. Murray, and S. Cunningham-Rundles. 1981. An outbreak of community acquired Pneumocystis carinii pneumonia: initial manifestation of cellular immune dysfunction. N. Engl. J. Med. 305:14311438.

5. Siegal, F. P., C. Lopez, G. S. Hammer, A. E. Brown, S. J. Kornfeld, J. Gold, J. Hassett, S. Z. Hirschman, C. Cunningham- 
Rundles, B. R. Adelsberg, D. M. Parham, M. Siegal, S. CunninghamRundles, and D. Armstrong. 1981. Severe acquired immunodeficiency in male homosexuals, manifested by chronic perianal ulcerative Herpes Simplex lesions. N. Engl. J. Med. 305:1439-1444.

6. Friedman-Kien, A. E., L. J. Laubenstein, P. Rubinstein, E. Buimovici-Klein, M. Marmor, R. Stahl, I. Spiglánd, K. S. Kim, and S. Zolla-Pazner. 1982. Disseminated Kaposi's sarcoma in homosexual men, Ann. Intern. Med. 96:693-700.

7. Mildvan, D., U. Mathur, R. W. Enlow, P. L. Romain, R. J. Winchester, C. Colp, H. Singman, B. R. Adelsberg, and I. Spigland. 1982. Opportunistic infections and immune deficiency in homosexual men. Ann. Intern. Med. 96:700-704.

8. Follansbee, S. E., D. F. Busch, C. B. Wofsy, D. L. Coleman, J. Gullet, G. P. Aurigerema, T. Ross, W. K. Hadley, and W. L. Drew. 1982. An outbreak of Pneumocystis carinii pneumonia in homosexual men. Ann. Intern. Med. 96:705-713.

9. Quinnan, G. V., H. Masur, A. H. Rook, G. Armstrong, W. R. Frederick, J. Epstein, J. F. Manischewitz, A. M. Macher, L. Jackson, J. Ames, H. A. Smith, M. Parker, G. R. Pearson, J. Parrillo, C. Mitchell, and S. E. Straus. 1984. Herpesvirus infections in the acquired immunodeficiency syndrome. JAMA (J. Am. Med. Assoc.). 252:72-77.

10. Macher, A. M., C. Reichert, S. E. Straus, D. L. Longo, J. Parrillo, H. C. Lane, A. S. Fauci, A. H. Rook, J. F. Manischewitz, and G. V. Quinnan, Jr. 1983. Death in the AIDS patient: role of cytomegalovirus. N. Engl. J. Med. 309:1454.

11. Rook, A. H., H. Masur, H. C. Lane, W. R. Frederick, T. Kasahara, A. M. Macher, J. Y. Djeu, J. F. Manischewitz, L. Jackson, A. S. Fauci, and G. V. Quinnan, Jr. 1983. Interleukin-2 enhances the depressed natural killer and cytomegalovirus-specific cytotoxic activities of lymphocytes from patients with the acquired immune deficiency syndrome. J. Clin. Invest. 72:398-403.

12. Quinnan, G. V., A. H. Rook, W. R. Frederick, J. F. Manischewitz, J. S. Epstein, J. P. Siegel, H. Masur, A. M. Macher, and J. Y. Djeu. 1985. Prevalence, clinical manifestations, and immunology of herpesvirus infections in the acquired immunodeficiency syndrome. Ann. NY Acad. Sci. 437:200-206.

13. Quinnan, G. V., Jr., N. Kirmani, A. H. Rook, J. F. Manischewitz, L. Jackson, G. Moreschi, G. W. Santos, R. Saral, and W. H. Burns. 1982. Cytotoxic $T$ cells in cytomegalovirus infection: HLA-restricted T-lymphocyte and non-T-lymphocyte cytotoxic responses correlate with recovery from cytomegalovirus infection in bone marrow transplant recipients. N. Engl. J. Med. 307:7-13.

14. Rook, A. H., G. V. Quinnan, W. R. Frederick, J. F. Manischewitz, N. Kirmani, T. Dantzler, B. B. Lee, and C. B. Currier, Jr. 1984. Importance of cytotoxic lymphocytes during cytomegalovirus infection of renal transplant recipients. Am. J. Med. 76:385-392.

15. Henney, C. S., K. Kuribayashi, D. E. Kern, and S. Gillis. 1981. Interleukin-2 augments natural killer cell activity. Nature (Lond.). 291: 335-338.

16. Smith, K. A. 1980. T-cell growth factor. Immunol. Rev. 51: 337-357.

17. Farrar, J. J., W. R. Benjamin, M. L. Hilfiker, M. Howard, W. L. Farrar, and J. Fuller-Farrar. The biochemistry, biology, and role of interleukin-2 in the induction of cytotoxic $\mathrm{T}$ cell and antibodyforming B cell responses. Immunol. Rev. 63:129-166.

18. Quinnan, G. V., Jr., M. Delery, A. H. Rook, W. R. Frederick, J. S. Epstein, J. F. Manischewitz, L. Jackson, K. M. Ramsey, K. Mittal, S. A. Plotkin, and M. R. Hilleman. 1984. Comparative virulence and immunogenicity of the Towne strain and a non-attenuated strain of cytomegalovirus. Ann. Intern. Med. 101:478-483.

19. Timonen, T., J. R. Ortaldo, and R. B. Herberman. 1982. Analysis of a single cell cytotoxicity assay of natural killer (NK) cell frequencies among human large granular lymphocytes and the effects of interferon on their activity. J. Immunol. 128:2514-2521.

20. Leonard, W. J., J. M. Depper, T. Uchiyama, K. A. Smith, T. A. Waldmann, and W. C. Greene. 1982. A monoclonal antibody that appears to recognize the receptor for human T-cell growth factor; partial characterization of the receptor. Nature (Lond.). 300:267-269.

21. Gillis, S., M. M. Ferm, W. Ou, and K. A. Smith. 1978. T cell growth factor: parameters of production and a quantitative microassay for activity. J. Immunol. 120:2027-2032.

22. Djeu, J. Y., T. Kasahara, J. E. Balow, and G. C. Tsokos. 1983. An interleukin-2 inhibitor is present in normal sera and is decreased in sera of patients with connective tissue disorders. Clin. Res. 31:342A.

23. Zoon, K., M. E. Smith, P. J. Bridgen, D. Zur Nedden, and C. B. Anfinsen. 1979. Purification and partial characterization of human lymphoblastoid interferon. Proc. Natl. Acad. Sci. USA. 76: 5601-5605.

24. Mancini, G., A. O. Carbonara, and J. F. Heremans. 1965. Immunochemical quantitation of antigens by single radial immunodiffusion. Immunochemistry. 2:235-254.

25. Rappaport, R. S., and G. R. Dodge. 1982. Prostaglandin E inhibits the production of human interleukin-2. J. Exp. Med. 155: 943-948.

26. Chouaib, S., and D. Fradelizi. 1982. The mechanism of human IL 2 production. J. Immunol. 129:2463-2468.

27. Kasahara, T., J. Y. Djeu, S. F. Dougherty, and J. J. Oppenheim. 1983. Capacity of human large granular lymphocytes (LGL) to produce multiple lymphokines: interleukin 2 , interferon, and colony stimulating factor. J. Immunol. 131:2379-2385.

28. DeStefano, E., R. M. Friedman, A. E. Friedman-Kien, J. J. Goedert, D. Henriksen, O. T. Preble, J. A. Sonnabend, and J. Vilcek. 1982. Acid-labile human leukocyte interferon in homosexual men with Kaposi's sarcoma and lymphadenopathy. J. Infect. Dis. 146:451-455.

29. Gillis, S., G. R. Crabtree, and K. A. Smith. 1979. Glucocorticoidinduced inhibition of $T$ cell growth factor production. I. The effect on mitogen-induced lymphocyte proliferation. J. Immunol. 123:16241631.

30. Cunningham-Rundles, S., M. A. Michelis, and H. Masur. 1983. Serum suppression of lymphocyte activation in vitro in acquired immunodeficiency disease. J. Clin. Immunol. 3:156-165.

31. Barre-Sinoussi, F., J. C. Chermann, F. Rey, M. T. Nugeyre, S. Chamaret, J. Gruest, D. Dauguet, C. Axler-Blin, F. Vezinet-Brun, C. Rouzioux, W. Rosenbaum, and L. Montagnier. 1983. Isolation of a T-lymphotropic retrovirus from a patient at risk for acquired immune deficiency syndrome (AIDS). Science (Wash. DC). 220:868-871.

32. Gallo, R. C., S, Z. Salahuddin, M. Popovic, G. M. Shearer, M. Kaplan, B. F. Haynes, T. J. Palker, R. Redfield, J. Oleske, B. Safai, G. White, P. Foster, and P. D. Markham. 1984. Frequent detection and isolation of cytopathic retroviruses (HTLV-III) from patients with AIDS and at risk for AIDS. Science (Wash. DC). 224:500-503.

33. Feorino, D. M., V. S. Kalyanaraman, H. W. Haverkos, C. D. Cabradilla, D. T. Warfield, H. W. Jaffe, A. K. Harrison, M. S. Gottlieb, D. Goldfinger, J.-C. Chermann, F. Barre-Sinoussi, T. T. Spira, J. S. McDougal, J. W. Curran, L. Montagnier, F. A. Murphy, and D. P. Francis. 1984. Lymphadenopathy associated virus infection of a blood donor-recipient pair with acquired immunodeficiency syndrome. Science (Wash. DC). 225:69-72.

34. Copelan, E. A., J. J. Rinehart, M. Lewis, L. Mathes, R. Olsen, and A. Sagone. 1983. The mechanism of retrovirus suppression of human T cell proliferation in vitro. J. Immunol. 131:2017-2020.

35. Kramer, M., and U. Koszinowski. 1982. T cell-specific suppressor factor(s) with regulatory influence on interleukin 2 production and function. J. Immunol. 128:784-790.

36. Hershey, P., C. Bindon, M. Czerniecki, A. Spurling, J. Wass, and W. H. McCarthy. 1983. Inhibition of interleukin 2 production by factors released from tumor cells. J. Immunol. 131:2837-2842.

37. Laurence, J., A. B. Gottlieb, and H. G. Kunkel. 1983. Soluble suppressor factors in patients with acquired immune deficiency syndrome and its prodrome: elaboration in vitro by $T$ lymphocyteadherent cell interactions. J. Clin. Invest. 72:2072-2081. 